\title{
IMPORTANCE OF SULPHATE-REDUCING BACTERIA IN ENVIRONMENT
}

\author{
ALENA LUPTAKOVA \\ Department of Mineral biotechnologies, Institute of Geotechnics \\ of Slovak Academy of Sciences, Watsonova 45, SK-043 53 Kosice, Slovak Republic \\ (luptakal@saske.sk)
}

\begin{abstract}
The sulphate-reducing bacteria represent the part of the biosphere, the active component in the cycle of elements in the biosphere and as shown by the existing knowledge they are becoming also the part of the environmental industrial technologies. The objective of this work was to give principal information concerning characteristics, the occurrence and the importance of sulphate-reducing bacteria in environment.
\end{abstract}

Key words: sulphate-reducing bacteria, sulphuretum, heavy metals

\section{Introduction}

Sulphate-reducing bacteria (SRB) are a ubiquitous group of anaerobic prokaryotes. They are unified by a shared ability to carry out sulphate reduction as a principal component of their bioenergetic processes. They are found in diverse environments and are of great utilitarian and academic interest. Their practical importance arises from both economic and environmental concerns. SRB are of significant economic interest in many industrial sectors. Their academic importance arises from the unique ecological and evolutionary roles they play. Sulphate reducers are important organisms in many anaerobic environments in nature, and their physiological activities are of profound importance for many ecological communities. Furthermore, there is increasing biochemical and genetic evidence suggesting that these organisms began evolutionary divergence at an early time. This long evolutionary history has led to development in these organisms of a variety of unique proteins and biochemical processes with profound academic importance and fundamental insights.

\subsection{Characteristics of sulphate-reducing bacteria}

The SRB represents a group of chemoorganotrophic and strictly anaerobic bacteria that may be divided into four groups based on rRNA sequence analysis (CASTRO et al., 1999): Gram-negative mesophilic SRB, Gram-positive spore forming SRB, thermophilic bacterial SRBand thermophilic archaeal SRB. They include genera such as Desulfovibrio, Desulfomicrobium, Desulfobacter, Desulfosarcina, Desulfotomacullum, Thermodesulfobacterium, Archaeoglobus, etc.

The basic metabolic process of SRB is the anaerobic reduction of sulphates in which organic substrate (lactate, malate, etc.) or gaseous hydrogen is the electron donor and sulphate is the electron acceptor. Considering the inorganic or organic 
character of energy source of SRB there are two types of anaerobic respiration of sulphates (ODOM and RIVERS SINGLETON, 1993):

1. Authotrophic reduction of sulphates - the energy source is a gaseous hydrogen, the reaction proceeds in several stages and the whole process can be summarily expressed by equation (1):

$4 \mathrm{H}_{2}+\mathrm{SO}_{4}^{2-} \longrightarrow \stackrel{\mathrm{SRB}}{\longrightarrow} \mathrm{S}^{2-}+4 \mathrm{H}_{2} \mathrm{O}$

2. Heterotrophic reduction of sulphates - the energy sources are simple organic substances (lactate, fumarate, pyruvate, some alcohols and the like). Depending on the final product of organic substrate oxidation we know:

- incomplete heterotrophic oxidation of organic substrate in which the final product is acetate (equation 2):

$2 \mathrm{CH}_{3} \mathrm{CHOHCOO}^{-}+\mathrm{SO}_{4}{ }^{2-} \stackrel{\mathrm{SRB}}{\longrightarrow} 2 \mathrm{CH}_{3} \mathrm{COO}^{-}+2 \mathrm{HCO}_{3}^{-}+\mathrm{H}_{2} \mathrm{~S}$

- complete heterotrophic oxidation of organic substrate in which the final products are $\mathrm{CO}_{2}$ and $\mathrm{H}_{2} \mathrm{O}$ (equation 3):

$4 \mathrm{CH}_{3} \mathrm{COCOONa}+5 \mathrm{MgSO}_{4} \rightarrow 5 \mathrm{MgCO}_{3}+2 \mathrm{Na}_{2} \mathrm{CO}_{3}+5 \mathrm{H}_{2} \mathrm{~S}+5 \mathrm{CO}_{2}+\mathrm{H}_{2} \mathrm{O}$

In the process of anaerobic respiration of sulphates SRB produce a considerable quantity of gaseous hydrogen sulphide $\left(\mathrm{H}_{2} \mathrm{~S}\right)$ which reacts easily in the water medium with heavy metal cations forming not easily dissoluble sulphides of the given metals (equation 4):

$\mathrm{Me}^{2+}+\mathrm{H}_{2} \mathrm{~S} \longrightarrow \mathrm{MeS}+2 \mathrm{H}^{+}\left(\mathrm{Me}^{2+}-\right.$ metal cation $)$

The typical species of SRB is Desulfovibrio desulfuricans (Fig. 1).

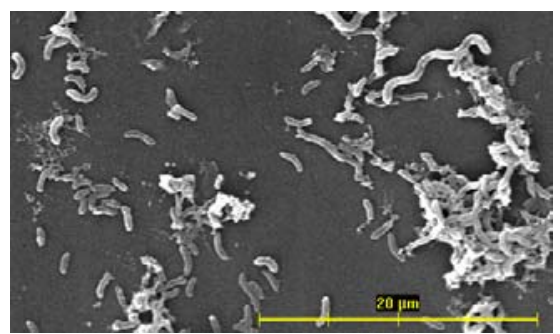

Fig. 1. Scanning electron micrograph of Desulfovibrio desulfuricans (LUPTÁKOVÁ, 2002)

\subsection{Occurrence of sulphate-reducing bacteria}

SRB are a unique and ubiquitous group of prokaryotic MO, found in a variety of anaerobic environmental niches such as:

- $\quad$ soil (RONALD, 1995), 
- mud and sediments of freshwaters (rivers, lakes, ...), thermal or no-thermal sulphur springs (KARAVAJKO et al., 1988, HO-YONG J. et al., 1996),

- mining waters from sulphide deposits (GROUDEVA and GROUDEV, 1997),

- waters from deposits of mineral oil and natural gas (ARMSTRONG et al., 1995),

- industrial waste waters (metallurgical industry (LUPTÁKOVÁ, 2002),

- sea and ocean (POSTGATE, 1982),

- gastrointestinal tract of man and animals (SNEATH et al., 1996).

\subsection{Importance of sulphate-reducing bacteria}

The metabolic actions of SRB described by equations 1-4 are the fundamental of SRB importance in environment. They are generator of many processes both positive and negative. Despite the odoriferous physiology of these organisms, they are important to study for both practical and academic reasons. Their practical importance stems from the significant economic impact they have in many industrial and ecological areas. Their academic importance is related to their unique environmental and evolutionary roles in nature.

Because SRB are ubiquitous to oil-bearing shale and strata they play an important economic role in many aspects of oil technology (DOCKINS et al., 1980). They are responsible for extensive corrosion of drilling and pumping machinery and storage tanks. Furthermore, because they contaminate resulting crude oil the organisms cause release of hydrogen sulphide into petroleum products, thereby increasing the sulphur level of fuels. They are also important in secondary oil recovery processes, where bacterial growth in injection waters can plug machinery used in these processes. It has also been suggested that these organisms may play a role in biogenesis of oil hydrocarbons. For all of these reasons SRB are of vital importance in petroleumproducing and processing-industries (POSTGATE, 1982).

A major economic consequence resulting from the metabolic action of SRB is anaerobic corrosion of underground buried ferrous metals such as tanks and pipelines. SRB play a vital role in a variety of other important economic areas. In many industrial processes they produced iron sulphides, thereby causing blackening and discoloration of products. For example, in the paper industries SRB can contaminate processing water, leading to sulphide production, which causes blackening of paper (ODOM and RIVERS SINGLETON, 1993).

\subsection{Environmental importance of SRB}

These organisms are also of great ecological importance, which is in part related to their economic importance. Pivotal ecological roles of SRB result from their participation in the sulphur cycle, which is a major biogeological cycle in nature. Sulphur is widely distributed on earth and occurs predominantly bound as sulphides in the form of sulphates or even as elemental sulphur. In nature sulphur circulates permanently because it is continuously oxidized or reduced by chemical or biological processes. In such a biogeochemical sulphur cycle (Fig. 2) the biological transformations may have either assimilatory or dissimilatory metabolic functions. 
With the exception of animals and humans, most plants, fungi and bacteria are capable of performing an assimilatory reduction of sulphate to sulphide which is necessary for the biosynthesis of sulphur containing cell compounds. On the other hand the energy producing dissimilatory sulphur metabolism is restricted to a few groups of bacteria. These groups include MO such as: anaerobic dissimilatory sulphate reducers (Desulfovibrio, Desulfotomaculum, Desulfomonas,....), anaerobic dissimilatory sulphur reducers (Desulfuromonas, Beggiatoa,....), anaerobic phototrophic sulphur oxidisers (some cyanobacteria and most anoxygenic phototrophic bacteria), aerobic chemotrophic sulphur oxidisers (Thiobacillus, Sulfolobus, Thiospira, Thiobacterium,....), anaerobic chemotrophic sulphur oxidisers (Thibacillus denitrificans, Thiomicrospira denitrificans,..) (REHM and REED, 1981).

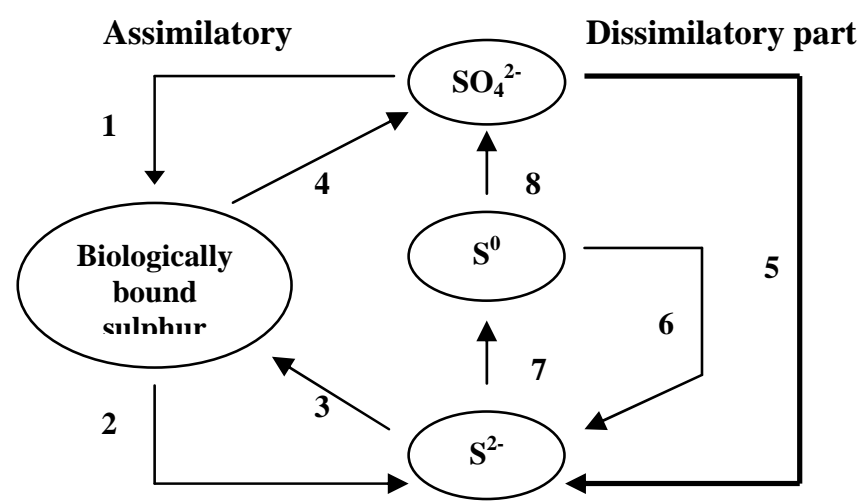

Fig. 2. The biological sulphur cycle (REHM and REED, 1981).

1 - assimilatory sulphate reduction by plants, fungi and bacteria; 2 - death and decomposition by fungi and bacteria; 3 - sulphide assimilation by bacteria and some plants; 4 - excretion of sulphate by animals; 5 dissimilatory sulphate-reducing bacteria; 6 - dissimilatory sulphur-reducing bacteria; 7 - phototrophic and chemotrophic sulphide-oxdizing bacteria; 8 - phototrophic and chemotrophic sulphur-oxidizing bacteria.

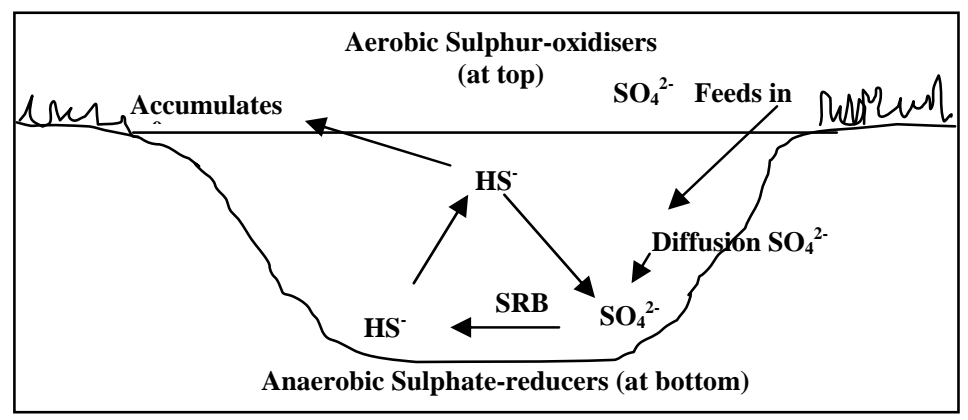

Fig. 3. Schematic diagram illustrating the chemical processes of a sulphuretum (ODOM and RIVERS SINGLETON, 1993)

As can be seen from Fig. 2 the SRB miss the assimilatory part of the cycle and produce sulphides. The microbial population of this dissimilatory part is called 
"sulphuretum" and its activity from the chemical processes point of view is shown in Fig. 3.

Sulphate ion from the surrounding land mass is leached into and diffuses to the bottom of these small aquatic systems, where it is reduced to $\mathrm{S}^{2-}$ by anaerobic sulphate-reducing bacteria. Sulphite ion then diffuses upward through the water column to the surface layers, where it is oxidized by aerobic organisms to either elemental sulphur $\left(\mathrm{S}^{0}\right)$ or $\mathrm{SO}_{4}{ }^{2-}$. The latter diffuses to the bottom, anaerobic region where the cycle continues. Because of its low solubility in water, however, $\mathrm{S}^{0}$ precipitates from solution and forms a yellow crust on the water surface and near the edges of these systems. The activity of sulphuretum is a basis of many processes in nature and it finds its application in industry, for example:

- the removal of heavy metals from industrial waste waters (e.g. Acid Mine Drainage) (KONTOPOULOS, 1998; BOONSTRA et al., 1999),

- $\quad$ the removal of $\mathrm{SO}_{4}{ }^{2-}$ from mine waters (KONTOPOULOS, 1998; GLOMBITZA, 2001),

- $\quad$ the production of sulphur from waste waters (POSTGATE, 1982),

- the removal of sulphur from crude oil, petrol and coal (desulphurization) (ARMSTRONG, 1997).

\subsection{Evolutionary importance of SRB}

There appears to be clear geochemical evidence that process of biological sulphate reduction is evolutionarily ancient. This conclusion grows from the observation that bacterial reduction of sulphate shows a kinetic isotope effect in which ${ }^{32} \mathrm{SO}_{4}{ }^{2-}$ is used more rapidly than the heavier isotope ${ }^{34} \mathrm{SO}_{4}{ }^{2-}$. Consequently, geological sulphur deposits that are enriched in the lighter isotope, relative to the heavier isotope are believed to be biological in origin. Evidence of this nature suggests that many of the world's sulphur reserves were biologically formed and that this action occurred prior to significant accumulation of atmospheric oxygen. This line of reasoning clearly suggests that the process of sulphate reduction was of bioenergetic significance before the process of oxygen reduction. Present arguments suggest that development of dissimilatory sulphate reduction occurred between 2.8 and $2.5 \times 10^{9}$ years ago and was simultaneous with oxygenic photosynthesis by ancestral cyanobacteria but prior to aerobic respiration (WIDDEL, 1988).

\section{Conclusion}

This paper attempts to give the notion that SRB were unified by shared ability to utilize sulphate reduction as an important component of their bioenergetics processes. SRB represent the part of the biosphere, the active component in the cycle of elements in the biosphere and as shown by the existing knowledge they are becoming also the part of the environmental industrial technologies. These bacteria are extremely diverse from metabolic, morphological, antigenic as well as ecological perspectives. This diversity will have profound implications for our understanding of the environmental and economic role that these bacteria play in the natural world. 
Acknowledgment: This work was supported by the Slovak Research and Development Agency under the contract No. APVV-51-027705 and grant agency VEGA for project No. 2/5148/27.

\section{References}

ARMSTRONG, S.M., SANKEY, B.M., VOORDOUW, G.: Converzion of Dibenzothiophene to Biphenyl by Sulfate-reducing Bacteria Isolated from Oil Field Production Facilities. Biotechnol. Lett., 17, 1995, 1133-1136.

ARMSTRONG, S.M., SANKEY, B.M., VOORDOUW, G.: Evaluation of Sulfatereducing bacteria for desulfurizing bitumen or its fractions. Fuel, 76,1997, 223227.

BOONSTRA, J., VAN LIER, R., JANSSEN, G., DIJKMAN, H., BUISMAN, C. J. N.: Biological Treatment of Acid Mine Drainage. In: R. AMILS, A. BALLESTER (Eds.) Biohydrometallurgy and the Environment toward the mining of the $21^{\text {st }}$ century, (Eds.). Elsevier, Amsterdam, 1999, 559-566.

CASTRO, H. F., WILLIAMS, N. H., OGRAM, A.: Phylogeny of Sulphate-reducing bacteria. FEMS Microbiol. Ecol., 31, 1999, 1-9.

DOCKINS, W. S., OLSON, G.J., MCFETERS, G. A., TURBAK, S. C.: Dissimilatory bascterial sulphate reduction in Montana ground water. Geomicrobiol. J., 2, 1980, 83-98.

GLOMBITZA, F.: Treatment of acid lignite mine flooding water by means of microbial sulfate reduction. Waste Manag., 21, 2001, 197-203.

GROUDEVA, V.I., GROUDEV, S.N.: Bioremediation of Acide Drainage waters. Proceedings of International Biohydrometallurgy Symposium. Sydney, Australia, 1997, 4-7.

JIN, H. Y., LEE, D. H., ZO, Y. G., KANG, C. S., KIM, S. J.: Distribution and Activity of Sulfate-reducing Bacteria in Lake Soyang Sediments. J. Microbiol., 34, 1996, $131-136$.

KARAVAJKO, G. I., ROSSI, G., AGATE, A. D., GROUDEV, S. N., AVAKYAN, Z. N.: Biotechnology of metals, Centre of projects GKNT, Moscow, 1988, 59 pp.

KONTOPOULOS, A.: Acid Mine Drainage Control. In: Effluent Treatment in the Mining Industry, Univesity of Concepcion, Chile, 1998, $57 \mathrm{pp}$.

LUPTÁKOVÁ, A., KUŠNIEROVÁ, M., FEČKO, P.: Minerálne biotechnológie II., sulfuretum v prírode a v priemysle. ES VŠB - Technická univerzita Ostrava, 2002.

ODOM, J. M., RIVERS SINGLETON, J. R.: The Sulfate-reducing Bacteria: Contemporary Perspectives, Springer-Verlag, New York, 1993.

POSTGATE, J.: Mikróby a my, Praha, Pyramída, 1982.

REHM, H.J., REED, G.: Biotechnology, Vol. 6b, Verlag Chemie GmbH, Weuheim, 1981, 473-475.

RONALD, M. A.: Principles of Microbiology, Mosbi -Year Book, 1995.

SNEATH, P.H., MAIR, N.S., SHARPE, M.E., HOLT, J.G.: Bergey's Manual of Systematic Bacteriology, Vol. 2, Vol. 8, Sydney, 1200-1202, 1996, 663-679.

WIDDEL, F.: Microbiology and ecology of sulphate- and sulphur- reducing bacteria. In: A.J.B ZEHNER (Ed.) Biology of Anaerobic Organisms, John Wile, New York, 1988, 469-585. 